\title{
The Documentation of Ancestral Caddo Ceramic Vessels from Two Sites in Camp and Upshur Counties in the Cypress Creek Basin in East Texas
}

Timothy K. Perttula

Follow this and additional works at: https://scholarworks.sfasu.edu/ita

Part of the American Material Culture Commons, Archaeological Anthropology Commons, Environmental Studies Commons, Other American Studies Commons, Other Arts and Humanities Commons, Other History of Art, Architecture, and Archaeology Commons, and the United States History Commons

Tell us how this article helped you.

This Article is brought to you for free and open access by the Center for Regional Heritage Research at SFA ScholarWorks. It has been accepted for inclusion in Index of Texas Archaeology: Open Access Gray Literature from the Lone Star State by an authorized editor of SFA ScholarWorks. For more information, please contact cdsscholarworks@sfasu.edu. 


\section{The Documentation of Ancestral Caddo Ceramic Vessels from Two Sites in}

Camp and Upshur Counties in the Cypress Creek Basin in East Texas

\section{Creative Commons License}

\section{(c) (1) (8)}

This work is licensed under a Creative Commons Attribution-NonCommercial 4.0 International License 


\title{
The Documentation of Ancestral Caddo Ceramic Vessels from Two Sites in Camp and Upshur Counties in the Cypress Creek Basin in East Texas
}

\author{
Timothy K. Perttula
}

In the early 1930s, University of Texas archaeologists obtained ancestral Caddo ceramic vessels from probable burial features at two Caddo sites in Camp and Upshur counties in the Big Cypress Creek basin of East Texas (Figure 1). The vessels from the Sam G. Roberts (41CP8, n=1) and the J. H. Brown (41UR7, n=4) sites in the Texas Archeological Research Laboratory (TARL) vessel collections are fully documented in this article.

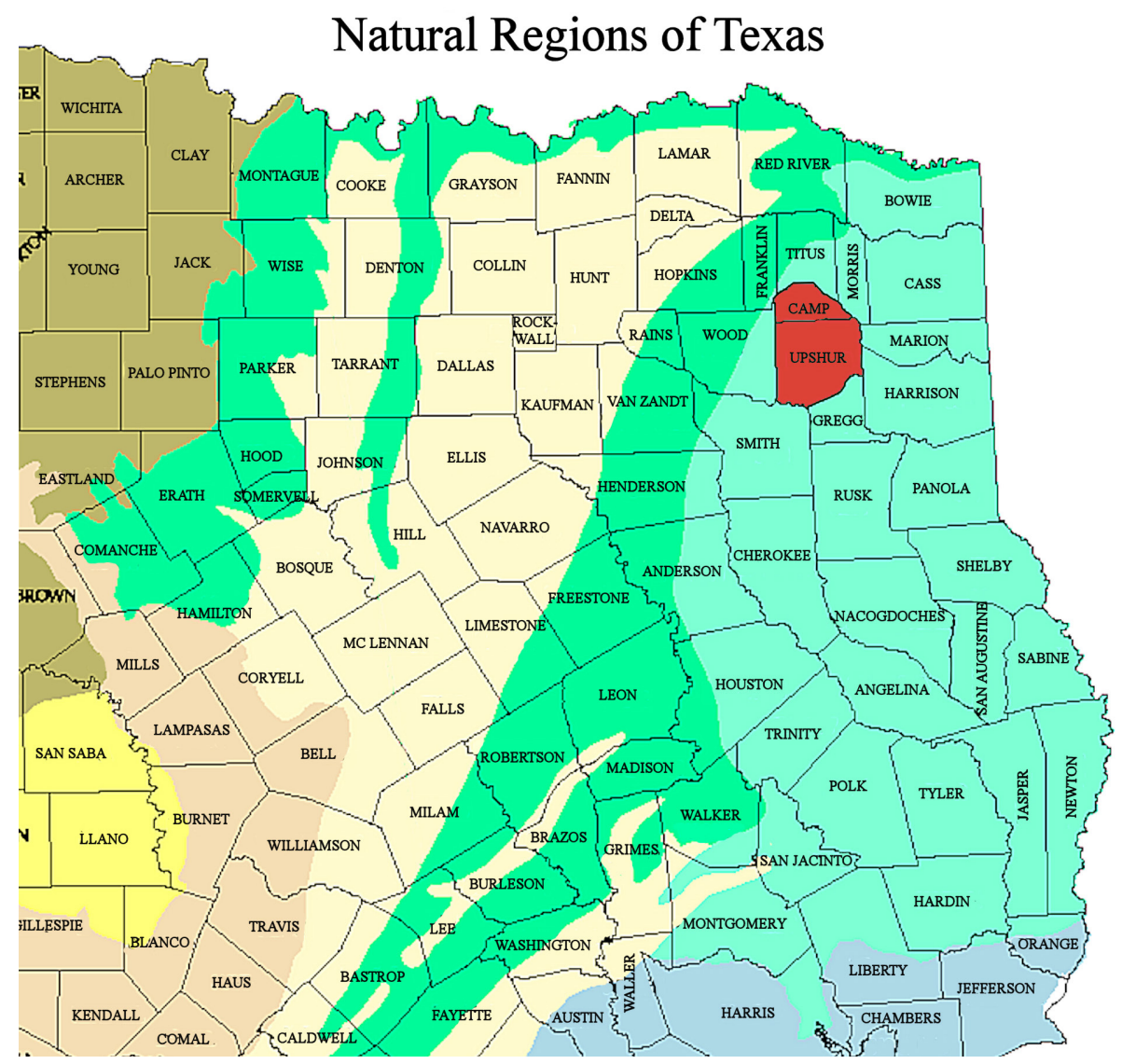

Figure 1. The locations of Camp and Upshur counties in East Texas.

\section{Sam G. Roberts (41CP8)}

The one ancestral Caddo ceramic vessel from the Sam G. Roberts site on Prairie Creek had been exposed by floodwaters in 1931, and UT archaeologists purchased the vessel in May 1931 from a Mr. H. M. Coffman. The exact location of the burial that had the ceramic vessel is not known, but it could have come from either habitation or mound contexts at the expansive site (ca. 8-10 acres) (see Thurmond 1990:144; Tunnell 1959). The site has one constructed mound (15.2 x $13.7 \mathrm{~m}$ in size and $1.1 \mathrm{~m}$ in height) 
south of the creek as well as several habitation areas southeast and east of the mound. The principal occupation was during Late Caddo period Titus phase times in Area A, perhaps in the latter part of the Titus phase based on the occurrence of Ripley Engraved, var. McKinney vessel sherds and Talco arrow points in this area east of the sub-structural mound (Thurmond 1990:144): the mound capped a burned circular Caddo structure (Thurmond 1990:50; Tunnell 1959) of Late Caddo period construction. Conventional radiocarbon dates of $240 \pm 90$ B.P. and $320 \pm 60$ B.P. from the burned structure indicates it dates to the latter part of the Titus phase (Thurmond 1990:Table 25).

SITE NAME OR SITE NUMBER: Sam G. Roberts

VESSEL NO.: 1

VESSEL FORM: Bottle (missing the neck, Figure 2a)

NON-PLASTICS AND PASTE: grog and hematite

RIM AND LIP FORM: N/A

CORE COLOR: $\mathrm{G}$ (fired in a reducing environment and cooled in the open air)

INTERIOR SURFACE COLOR: dark gray

EXTERIOR SURFACE COLOR: yellowish-brown; fire clouds on the rim, body, and base

WALL THICKNESS (IN MM): neck, $6.2 \mathrm{~mm}$

INTERIOR SURFACE TREATMENT: none

EXTERIOR SURFACE TREATMENT: smoothed

HEIGHT (IN CM): 10.5+

ORIFICE DIAMETER (IN CM): N/A

DIAMETER AT BOTTOM OF RIM OR NECK (IN

$\mathrm{CM}$ ): $3.7 \mathrm{~cm}$; maximum body diameter: $9.5 \mathrm{~cm}$

BASE DIAMETER (IN CM) AND SHAPE OF

BASE: $7.0 \mathrm{~cm}$, circular and flat

\section{ESTIMATED VOLUME (IN LITERS): 0.3+}

\section{DECORATION (INCLUDING MOTIF AND}

ELEMENTS WHEN APPARENT): The vessel body has a series of 11 vertical engraved panels below a series of short widely-spaced vertical engraved lines (Figure 2b). Eight of the vertical engraved panels have cross-hatched engraved lines, and interspersed between these are three panels with diagonal engraved lines pitched in different directions (Figure 2b).
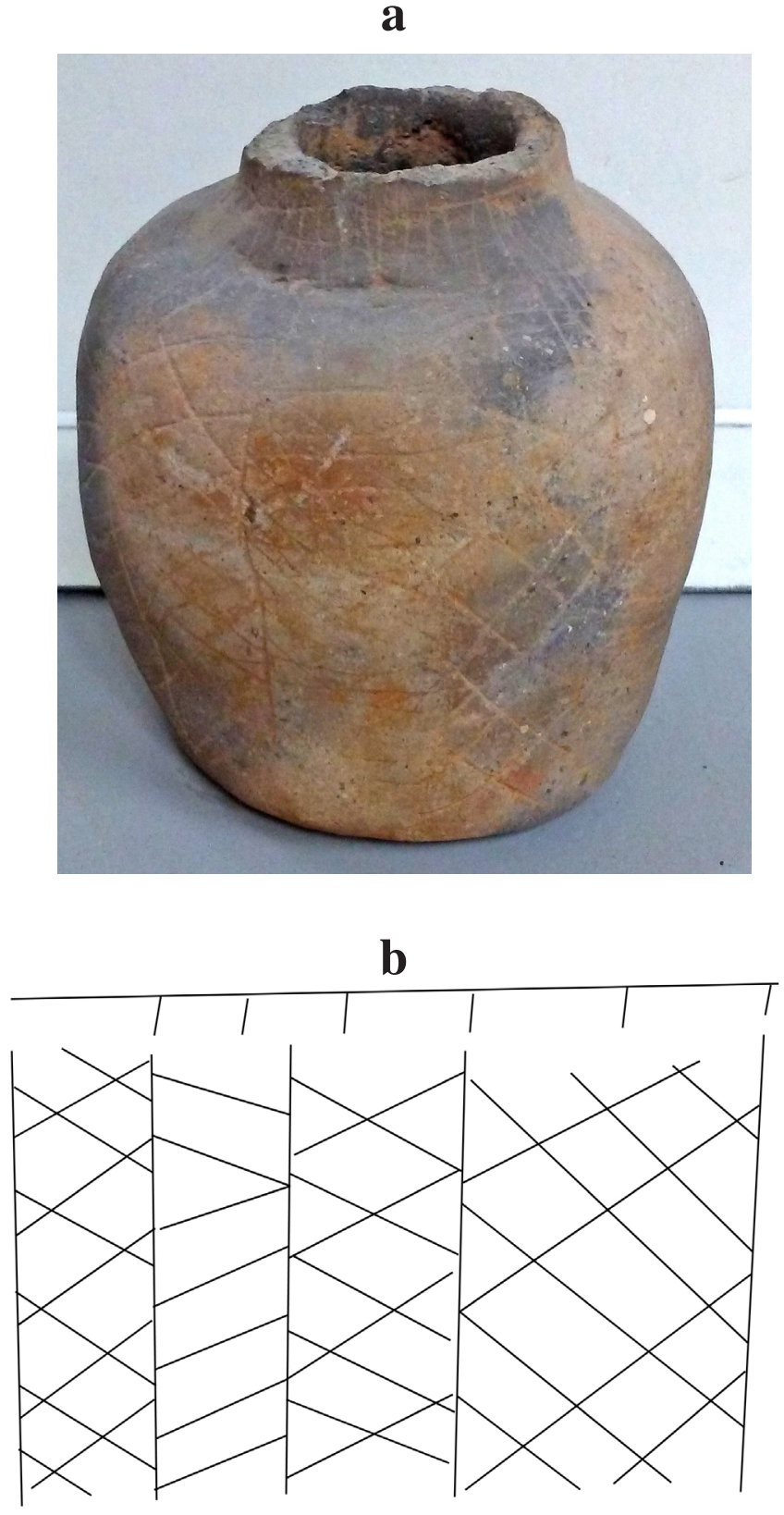

Figure 2. Engraved bottle (No. 1) from the Sam G. Roberts site: a, photograph; b, decorative elements. 
PIGMENT USE AND LOCATION ON VESSEL: none

TYPE AND VARIETY (IF KNOWN): Unidentified fine ware

\section{J. H. Brown (41UR7)}

The ceramic vessels from the J. H. Brown site were donated to the University of Texas by the landowner in 1931.

SITE NAME OR SITE NUMBER: J. H. Brown

VESSEL NO.: 1

VESSEL FORM: Compound bowl with four rim peaks and two strap handles $(27 \mathrm{x} 78 \mathrm{~mm}$ in length and width) (Figure 3a-b)

NON-PLASTICS AND PASTE: grog and bone

RIM AND LIP FORM: Everted rim and rounded lip

CORE COLOR: B (fired and cooled in a reducing environment)

INTERIOR SURFACE COLOR: very dark gray

EXTERIOR SURFACE COLOR: gray; fire clouds on the rim and body

WALL THICKNESS (IN MM): upper rim panel, $5.3 \mathrm{~mm}$; lower rim panel, $6.0 \mathrm{~mm}$; body, $6.0 \mathrm{~mm}$

INTERIOR SURFACE TREATMENT: smoothed

EXTERIOR SURFACE TREATMENT: smoothed

HEIGHT (IN CM): 9.9+; rim peak height: 10.2+

ORIFICE DIAMETER (IN CM): 18.0

DIAMETER AT BOTTOM OF RIM OR NECK (IN CM): upper rim panel, $18.0 \mathrm{~cm}$; lower rim panel, $18.4 \mathrm{~cm}$

\section{BASE DIAMETER (IN CM) AND SHAPE OF BASE: N/A}

ESTIMATED VOLUME (IN LITERS): $1.4+$

DECORATION (INCLUDING MOTIF AND ELEMENTS WHEN APPARENT): The two opposed strap handles have a central appliqued node at the center of a curvilinear scroll line (Figure 3a-b). Above and below and on either side of the appliqued node are pendant triangular areas that are either filled with cross-hatched lines or excised areas. 
The upper rim panel has three horizontal engraved lines (Figure 3b) as well as the rim peaks decorated with curvilinear engraved lines and zones filled with hatched lines or excised areas. The lower rim panel has two opposed appliqued nodes (Figure 3a) with upper and lower triangular engraved zones on either side of the nodes. There is a curvilinear excised area above the nodes, and the triangular zones have inner excised triangle elements, with or without negative oval elements.

PIGMENT USE AND LOCATION ON VESSEL: white pigment in the engraved lines

TYPE AND VARIETY (IF KNOWN): Turner Engraved, var. Horton
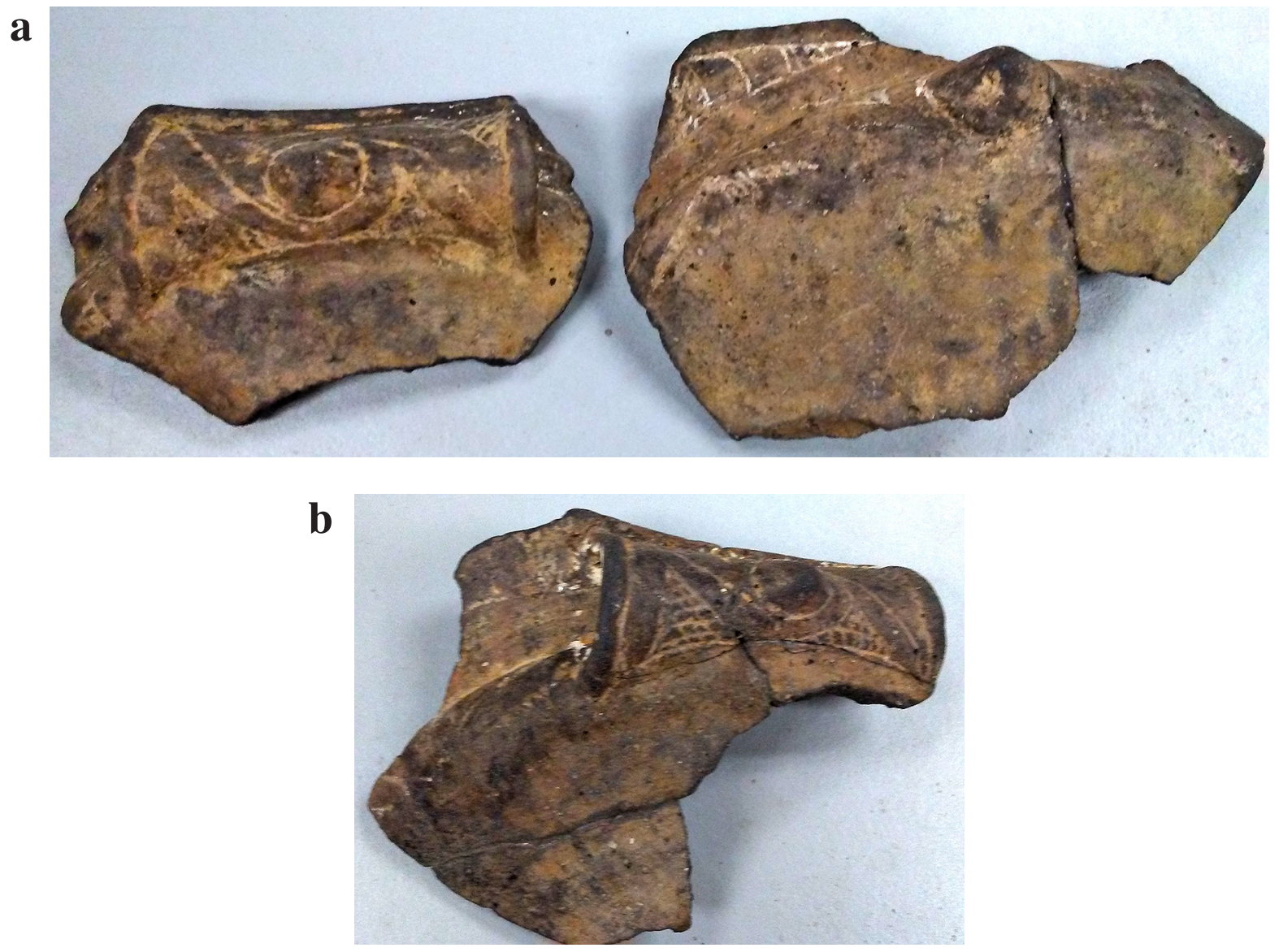

Figure 3. Rim sherds from the upper and lower rim panels of a Turner Engraved, var. Horton compound bowl (No. 1) from the J. H. Brown site: a, upper and lower rim panels and strap handle; b, strap handle.

SITE NAME OR SITE NUMBER: J. H. Brown

VESSEL NO.: 3

VESSEL FORM: Jar (body and base only)

NON-PLASTICS AND PASTE: grog

RIM AND LIP FORM: N/A

CORE COLOR: $\mathrm{H}$ (fired in a reducing environment and cooled in the open air) 
INTERIOR SURFACE COLOR: yellowish-brown

EXTERIOR SURFACE COLOR: dark gray; fire clouds on the body and base

WALL THICKNESS (IN MM): body, $7.3 \mathrm{~mm}$

INTERIOR SURFACE TREATMENT: smoothed

EXTERIOR SURFACE TREATMENT: smoothed

HEIGHT (IN CM): 5.6+

ORIFICE DIAMETER (IN CM): N/A

DIAMETER AT BOTTOM OF RIM OR NECK (IN CM): 10.5

BASE DIAMETER (IN CM) AND SHAPE OF

BASE: $6.4 \mathrm{~cm}$, circular and flat

ESTIMATED VOLUME (IN LITERS): N/A

DECORATION (INCLUDING MOTIF AND

ELEMENTS WHEN APPARENT): Plain (Figure 4)

PIGMENT USE AND LOCATION ON VESSEL: none

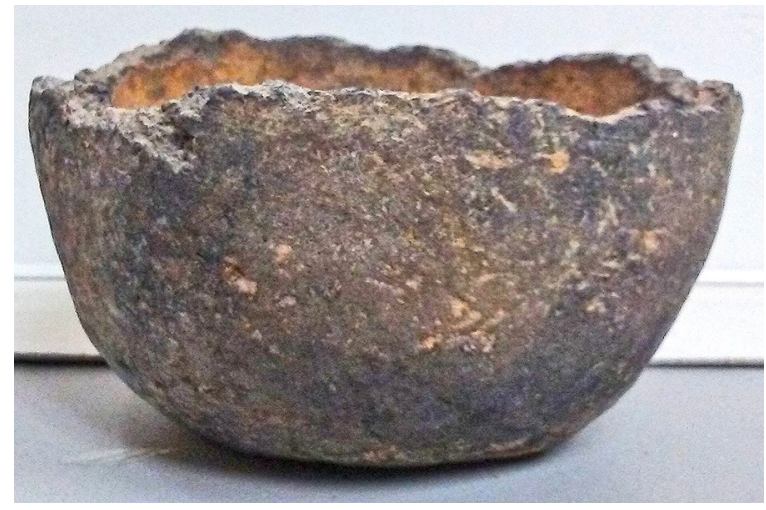

Figure 4. Plain jar body and base section (No. 3) from the J. H. Brown site.

TYPE AND VARIETY (IF KNOWN): Unidentified plain ware

SITE NAME OR SITE NUMBER: J. H. Brown

VESSEL NO.: 4

VESSEL FORM: Bowl (Figure 5a)

NON-PLASTICS AND PASTE: grog, bone, and hematite

RIM AND LIP FORM: Direct rim and rounded lip

CORE COLOR: F (fired in a reducing environment and cooled in the open air)

INTERIOR SURFACE COLOR: reddish-brown; fire clouds on the body and base

EXTERIOR SURFACE COLOR: reddish-brown; fire clouds on the rim, body, and base

WALL THICKNESS (IN MM): rim, $6.2 \mathrm{~mm}$; body, $6.5 \mathrm{~mm}$

INTERIOR SURFACE TREATMENT: smoothed 
EXTERIOR SURFACE TREATMENT: smoothed

HEIGHT (IN CM): 8.3

ORIFICE DIAMETER (IN CM): 14.3

DIAMETER AT BOTTOM OF RIM OR NECK (IN $\mathrm{CM}): \mathrm{N} / \mathrm{A}$

BASE DIAMETER (IN CM) AND SHAPE OF BASE: $6.9 \mathrm{~cm}$, circular and flat

ESTIMATED VOLUME (IN LITERS): 0.5

\section{DECORATION (INCLUDING MOTIF AND} ELEMENTS WHEN APPARENT): The vessel rim and body has four sets of upper and lower engraved nested triangle elements divided by a continuous diagonal engraved scroll line (Figure 5b). Above and below the scroll lines are large and small triangle elements, either with curvilinear hatched corners, or diagonal hatched zones and smaller, inner, hatched pendant triangles (Figure 5b).

PIGMENT USE AND LOCATION ON VESSEL: none $\mathbf{a}$

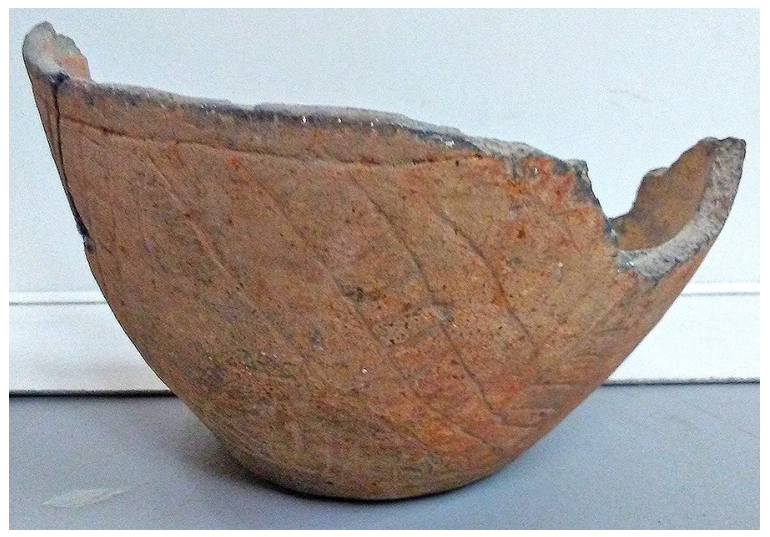

b

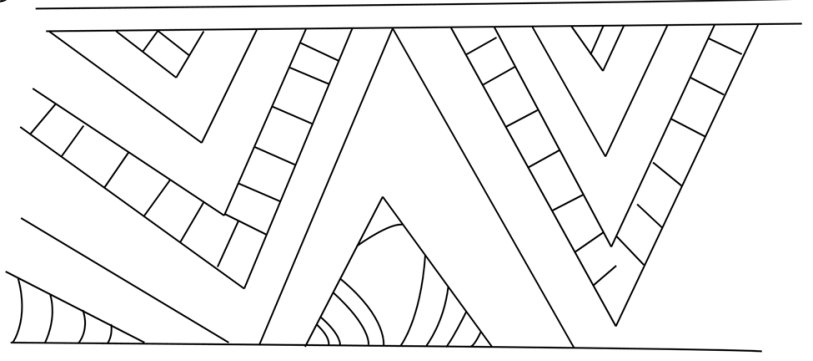

Figure 5. Ripley Engraved, var. Williams bowl (No. 4) from the J. H. Brown site: a, photograph; b, decorative elements.

TYPE AND VARIETY (IF KNOWN): Ripley Engraved, var. Williams

SITE NAME OR SITE NUMBER: J. H. Brown

VESSEL NO.: 5

VESSEL FORM: Carinated bowl

NON-PLASTICS AND PASTE: grog

RIM AND LIP FORM: Direct rim and a rounded lip

CORE COLOR: $\mathrm{H}$ (fired in a reducing environment and cooled in the open air)

INTERIOR SURFACE COLOR: reddish-brown; fire clouds on the rim and body

EXTERIOR SURFACE COLOR: dark gray; fire clouds on the rim and body; organic residue on the rim and body

WALL THICKNESS (IN MM): rim, $6.5 \mathrm{~mm}$

INTERIOR SURFACE TREATMENT: smoothed

EXTERIOR SURFACE TREATMENT: burnished 
HEIGHT (IN CM): 10.3

ORIFICE DIAMETER (IN CM): 17.8

DIAMETER AT BOTTOM OF RIM OR NECK (IN CM): 17.8

BASE DIAMETER (IN CM) AND SHAPE OF BASE: $8.3 \mathrm{~cm}$, circular and flat

\section{ESTIMATED VOLUME (IN LITERS): 1.1}

DECORATION (INCLUDING MOTIF AND ELEMENTS WHEN APPARENT): The rim panel is decorated with cross-hatched engraved lines surrounding four nested triangle elements (Figure 6). The nested triangles have diagonal hatched corners and negative circles with small inner circle elements.

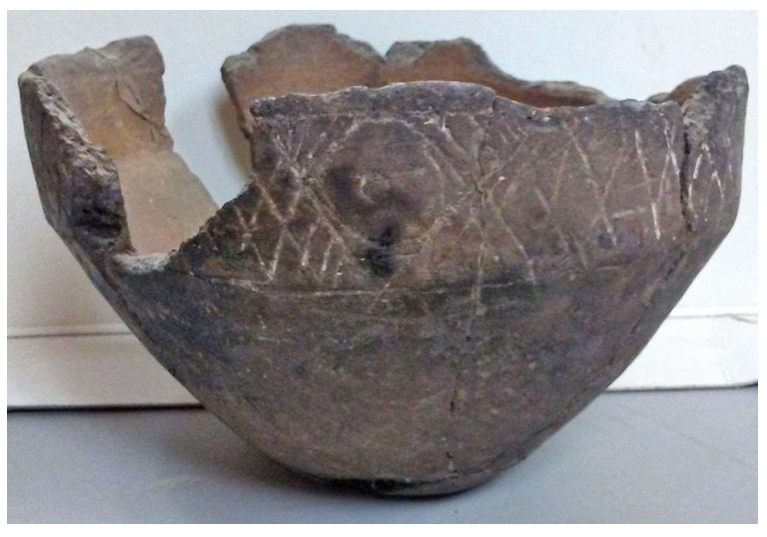

Figure 6. Engraved carinated bowl (No. 5) from the J. H. Brown site.

PIGMENT USE AND LOCATION ON VESSEL: white pigment in the engraved lines

TYPE AND VARIETY (IF KNOWN): Unidentified fine ware

\section{Summary and Conclusions}

The Texas Archeological Research Laboratory whole vessel collection has five vessels from two different ancestral Caddo sites in Camp and Upshur counties in the Big Cypress Creek basin that have been documented in this article. They include the Sam G. Roberts (41CP8) and the J. H. Brown (41UR7) sites. The grog-tempered $(n=2)$, grog-bone-tempered $(n=1)$, grog-hematite-tempered $(n=1)$, and grog-bonehematite-tempered $(n=1)$ vessels are from Late Caddo period Titus phase burial features, among them one plain jar from the J. H. Brown site, and four fine ware vessels, one to three vessels per site.

The fine wares from these two sites are stylistically and formally diverse, beginning with a Ripley Engraved, var. Williams bowl from the J. H. Brown site as well as a Turner Engraved, var. Horton compound bowl. A bottle of unidentified type with vertical engraved panels filled with either diagonal or cross-hatched engraved lines was found at the Sam G. Roberts site, a Titus phase mound center with extensive habitation deposits.

\section{Acknowledgments}

Thanks to the staff at the Texas Archeological Research Laboratory for providing access to their incomparable ancestral Caddo whole vessel collections. Lance Trask prepared several of the figures in this article.

\section{References Cited}

Thurmond, J. P.

1990 Archeology of the Cypress Creek Drainage Basin, Northeastern Texas and Northwestern Louisiana. Studies in Archeology 5. Texas Archeological Research Laboratory, The University of Texas at Austin.

Tunnell, C. D.

1959 The Sam Roberts Site, Ferrell's Bridge Reservoir, Texas. MS on file, Texas Archeological Research Laboratory, The University of Texas at Austin. 